The recognition of raised plasma concentrations of parathyroid hormone may be of value in the diagnosis of primary hyperparathyroidism, but insufficient patients have yet been studied to establish what degree of overlap may exist with cases of hypercalcaemia due to other causes. Nevertheless, the very high concentrations of parathyroid hormone found in the glandular effluent blood in the present study suggest that retrograde catheterization of the innominate and internal jugular veins may be of value in the preoperative localization of a tumour.

I wish to thank my surgical colleagues Mr. John Vinnecombe, Mr. John Webster, and Mr. John Lloyd-Davies for their unstinted co-operation and their good-natured tolerance in allowing me to collect samples during operation, and also the physicians and pathologists in the Wessex Region for all their kind help.

I should like to thank the Wessex Regional Hospital Board for its provision of the endocrine laboratory facilities and the Fleming Memorial Foundation, the Smith Kline and French Foundation, and the Dowager Countess Eleanor Peel Trust for their generous financial assistance.

\section{REFERENCES}

Aurbach, G. D. (1966).) Cited in Potts, J. T., et al. (1968).

Berson, S. A., and Yalow, R. S. (1966). Science, 154, 907.

Berson, S. A., and Yalow, R. S. (1968). Journal of Clinical Endocrinology, 28, 1037.

Berson, S. A., Yalow, R. S., Aurbach, G. D., and Potts, J. T. (1963). Proceedings of the National Academy of Sciences, 49, 613.

Buckle, R. M. (1968a). fournal of the Royal College of Physicians of London, 3, 77.

Buckle, R. M. (1968b). In Proceedings of the International Symposium on Protein and Polypeptide Hormones. Liege. In press.

Buckle, R. M., Aurbach, G. D., and Potts, J. T. (1968). In Protein and Polypeptide Hormones, edited by M. Margoulies, p. 389. Amsterdam, Excerpta Medica Foundation.
Buckle, R. M., Care, A. D., Cooper, C. W., and Gitelman, H. J. (1968). fournal of Endocrinology, 42, 529.

Buckle, R. M., Chase, L. R., Aurbach, G. D., and Potts, J. T. (1969). fournal of Laboratory and Clinical Medicine. Submitted for publication.

Care, A. D., Sherwood, L. M., Potts, J. T., and Aurbach, G. D. (1966). Nature, 209, 55.

Chase, L. R., and Aurbach, G. D. (1967). Proceedings of the National Academy of Sciences, 58, 518.

Copp, D. H. (1960). Bone as a Tissue, edited by K. Rodahl, J. T. Nicholson, and E. M. Brown, p. 289. New York, McGraw-Hill.

Greenwood, F. C., Hunter, W. M., and Glover, J. S. (1963). Biochemical fournal, 89, 114.

Herbert, V., Lau, K. S., Gottlieb, C. W., and Bleicher, S. J. (1965). fournal of Clinical Endocrinology and Metabolism, 25, 1375.

Mclick, R. A., Aurbach, G. D., and Potts, J. T. (1965). Endocrinology, 77, 198.

Melick, R. A., and Martin, T. J. (1968). In Parathyroid Hormone and Thyrocalcitonin, edited by R. V. Talmage and L. F. Bélanger, p. 440. Amsterdam, Excerpta Medica Foundation.

O'Riordan, J. L. H., Potts, J. T., and Aurbach, G. D. (1969). Proceedings of the Fifth European Symposium on Calcified Tissues. In

Parsons, J. A., and Robinson, C. J. (1968). fournal of Physiology, 194,

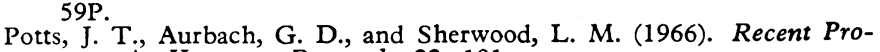
gress in Hormone Research, 22, 101

Potts, J. T., et al. (1968a). In Parathyroid Hormone and Thyrocalcitonin, edited by R. V. Talmage, and L. F. Bélanger, p. 407. Amsterdam, Excerpta Medica Foundation.

Potts, J. T., Deftos, L. J., Buckle, R. M., Sherwood, L. M., and Aurbach, G. D. (1968b). In Radioisotopes in Medicine: In Vitro Studies, edited by R. L. Hayes, F. A. Goswitz, and B. E. P. Murphy, p. 207. Tennessee, Oak Ridge Associated Universities.

Ramberg, C. F., Mayer, G. P., Kronfeld, D. S., Aurbach, G. D., Sherwood, L. M., and Potts, J. T. (1967). American fournal of Physiology, 213, 878.

Samols, E., and Bilkus, D. (1964). Proceedings of the Society for Experimental Biology and Medicine, 115, 79.

Sherwood, L. M., Mayer, G. P., Ramberg, C. F., Kronfeld, D. S., Aurbach, G. D., and Potts, J. T. (1968). Endocrinology, 83, 1043. Sherwood, L. M., O'Riordan, J. L. H., Aurbach, G. D., and Potts, J. T. (1967). Fournal of Clinical Endocrinology, 27, 140.

Talmage, R. V., Doty, S. B., Cooper, C. W., Yates, C., and Neuenschwander, J. (1965). In The Parathyroid Glands: Ultrastructure, Secretion and Function, edited by P. J. Gaillard, R. V. Talmage, Secretion and Function, edited by P. University of Chicago Press. Zisman, E., et al. (1968). American łournal of Medicine, 45, 619.

\title{
Metabolic Studies, Aldosterone Secretion Rate, and Plasma Renin after Carbenoxolone Sodium
}

\author{
J. H. BARON,; D.M., M.R.C.P.; J. D. N. NABARRO, † M.D., F.R.C.P.; J. D. H. SLATER, † M.A., M.R.C.P. \\ R. TUFFLEY, $\ddagger$ M.B., B.S., M.R.C.P.
}

\begin{abstract}
Summary : A formal metabolic study of carbenoxolone sodium (Biogastrone) $300 \mathrm{mg}$./day has been performed for 17 days on a woman with gastric ulcer who in a previous 21-day trial, on a 52-mEq sodium diet, showed weight gain, retention, and rise in plasma sodium and chloride concentrations, as well as hypokalaemia without change in potassium balance. In the present trial sodium intake was restricted to $26 \mathrm{mEq} /$ day; while plasma electrolyte changes of lesser degree still occurred, there was no retention of water, sodium, or chloride. Aldosterone secretion in the control period was $202 \mu \mathrm{g} . / 24$ hours, and fell to $74 \mu \mathrm{g} . / 24$ hours after carbenoxolone, but plasma renin was unchanged.

These results suggest that the mineralocorticoid effects of carbenoxolone (and presumably of liquorice and its other derivatives) are due to an intrinsic aldosterone-like action, and that, with sodium deprivation, aldosterone secretion is suppressed by a mechanism which is not renin-mediated-possibly hypokalaemia.
\end{abstract}

\section{Introduction}

We have previously reported detailed studies of the metabolic changes resulting from the administration of carbenoxolone sodium (Biogastrone), $300 \mathrm{mg}$./day for 21 days, to four patients with peptic ulcer (Baron and Nabarro, 1968). Weight gain and sodium and chloride retention were observed as well as hypokalaemia without appreciable changes in potassium balance. After reviewing the clinical, metabolic, and experimental studies of liquorice and glycyrrhizinic and glycyrrhetinic acids and their salts (carbenoxolone sodium is the sodium hemisuccinate of glycyrrhetinic acid) it was suggested that the metabolic actions of these compounds were essentially identical, varying with dose and duration of administration, and resembled those of aldosterone.

* Lately Senior Medical Registrar.

† Physician.

¥ Wellcome Research Fellow, Institute of Clinical Research. Institute of Clinical Research, the Middlesex Hospital Medical School,
London W.1. 
Measurements of plasma renin and aldosterone have not been made in patients given carbenoxolone sodium, and in order to test the hypothesis of an aldosterone-like action of carbenoxolone these measurements were made in a further study of one of the original four peptic ulcer patients.

\section{Method}

The patient (I. W.) was a 70-year-old widow with an ulcer on the lesser curve of the antrum of the stomach. She was a diabetic who was controlled by diet and twice-daily injections of soluble insulin. The present study was conducted similarly to the previous studies (Baron and Nabarro, 1968), but in this trial chemical analyses of faeces and isotopic studies of body compartments and ions were not made. Faecal outputs of electrolytes were assumed to be sodium $2 \mathrm{mEq} / \mathrm{day}$, chloride $2 \mathrm{mEq} /$ day, potassium $10 \mathrm{mEq} /$ day, in the same proportion of intake as in the previous trial. In this trial the dietary sodium was halved to $26 \mathrm{mEq} /$ day, the chloride content to $28 \mathrm{mEq} /$ day, with little change in potassium intake $(50 \mathrm{mEq} /$ day), and no change in the carbohydrate $80 \mathrm{~g}$. and protein $54 \mathrm{~g}$. constituents, but slight increase in calories to $1,000 /$ day.

After a five-day run-in period an eight-day control period of observation was made, followed by 17 days on carbenoxolone sodium as Biogastrone tablets $100 \mathrm{mg}$. three times a day before meals. On the last two days of the control period and the last two days of the drug period the following additional procedures were carried out. On the first of the two days at 8 a.m., with the patient fasting and supine, not having been out of bed from the previous night, $20 \mathrm{ml}$. of blood was withdrawn from a vein, heparinized, centrifuged, and the plasma separated and frozen. About $3 \mu \mathrm{Ci}$ of ${ }^{1,2} \mathrm{H}_{3}-(\mathrm{d}+)$-aldosterone$17 \beta$ was then injected intravenously. At 3 p.m., after the patient had been standing and walking for half an hour, a further $20 \mathrm{ml}$. of venous blood was taken. Urine was collected for 48 hours for determination of the aldosterone secretion rate from the specific activity of the acid-labile metabolite (Slater et al., 1969). Plasma renin was measured by an enzyme kinetic method (Slater et al., 1969 ; Tuffley and Slater, 1969).

\section{Results}

No clinical side-effects were observed. The metabolic results are shown in the Table.

Summary of Calculated Metabolic Changes in Patient I.W. in Previous Trial (fanuary 1967) and Present Trial (fanuary 1968) with Carbenoxolone Sodium

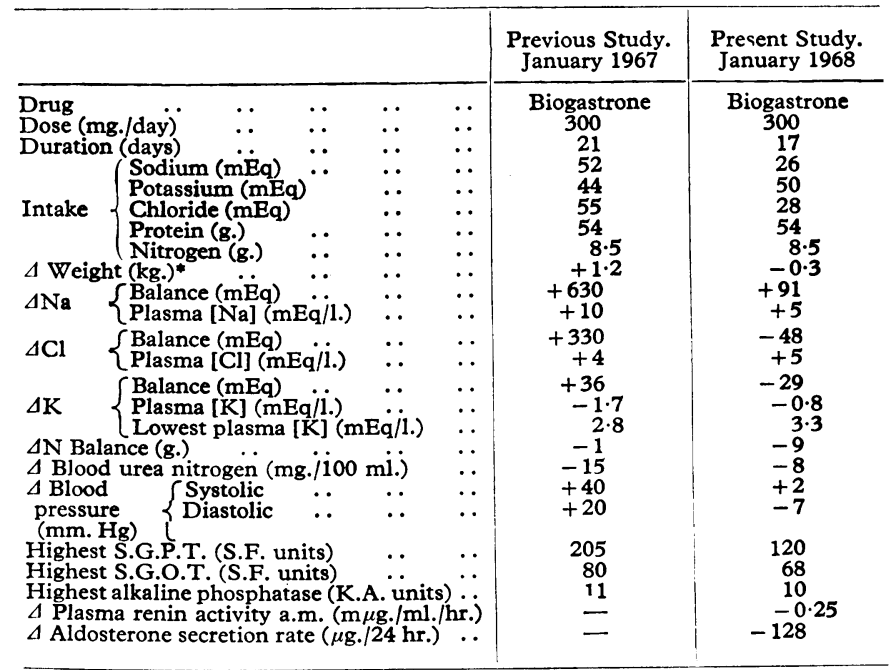

* The weight changes do not correspond with water, sodium, chloride balance, because in both studies the patient was on a low-calorie diet.
Body Weight.-The patient lost $0.3 \mathrm{~kg}$. in the control period, gained $0.5 \mathrm{~kg}$. in the first week of carbenoxolone, and then returned to near the pretreatment weight by the end of the 17 days on carbenoxolone. The overall weight change in this patient does not correspond with water balance, because she was on a low-calorie diet.

Sodium and Chloride.-The patient was in neutral sodium and chloride balance in the control week. The changes in sodium and chloride balance after carbenoxolone were very small.

Potassium.-There was negligible change in external potassium balance over the drug period, but plasma potassium concentration fell by about $0.8 \mathrm{mEq} / 1$.

Nitrogen.-The patient lost $9 \mathrm{~g}$. of nitrogen in the first three days on carbenoxolone, and there was no further change in external nitrogen balance over the next two weeks. Blood urea nitrogen fell during the drug period by $\delta \mathrm{mg} . / 100 \mathrm{ml}$.

Plasma Renin.-Eleven days after the low-sodium regimen had begun the angiotensin formation rate in plasma collected at 8.30 a.m. while the patient was still recumbent was 2.62 $\mathrm{m} \mu \mathrm{g} . / \mathrm{ml}$./hour \pm 0.60 (standard error of the estimate of the slope). On an unrestricted sodium intake our normal range is $0.3-1.5 \mathrm{~m} \mu \mathrm{g} . / \mathrm{ml}$./hour. At $3 \mathrm{p} . \mathrm{m}$. of the same day the angiotensin formation rate was $1.66 \mathrm{~m} \mu \mathrm{g} . / \mathrm{ml}$./hour \pm 0.11 . Fifteen days after the beginning of treatment with carbenoxolone and 28 days after the institution of the low-sodium regimen the angiotensin formation rate was $2.37 \mathrm{~m} \mu \mathrm{g} . / \mathrm{ml}$./ hour \pm 0.90 at 8.30 a.m. and $4.12 \mathrm{~m} \mu \mathrm{g} . / \mathrm{ml}$. hour \pm 0.50 at 12.30 p.m.

Aldosterone Secretion Rate.-At the end of the control period the aldosterone secretion rate was $202 \mu \mathrm{g}$. $/ 24$ hours (on a diet of unrestricted sodium content the normal range is 100-150 $\mu$ g. $/ 24$ hours). After 15 days on carbenoxolone this had fallen to $74 \mu \mathrm{g} . / 24$ hours, which is a low value for a restricted sodium intake.

Serum Enzymes.-There was no appreciable change in blood pressure, but a marked rise occurred in serum transaminases and alkaline phosphatase, with return to normal concentrations 16 days after the drug was stopped. There were no changes in haemoglobin, haematocrit reading, bilirubin, bicarbonate, or plasma proteins.

\section{Discussion}

The Table summarizes the results in the previous and present trial. Marked rises in hepatocellular enzymes were seen in both trials, with reversion to normal after the drug was stopped.

It will be seen that on a low-sodium intake $(26 \mathrm{mEq} /$ day $)$ there was negligible retention of sodium, chloride, and water, and no rise in blood pressure in contrast to the pronounced changes found in the patient's previous study on a higher sodium intake ( $52 \mathrm{mEq} /$ day). Rises in plasma concentrations of sodium and chloride and decreases in plasma potassium and blood urea did occur, but the changes in general were only about half those in the previous trial. External potassium and nitrogen balances were again essentially unchanged. Since about $2.7 \mathrm{mEq}$ of potassium is lost for each gramme of protein lost, the cumulative nitrogen balance of $-9 \cdot 2 \mathrm{~g}$. could account for $25 \mathrm{mEq}$ of the cumulative potassium balance of $-29 \mathrm{mEq}$. There was therefore no net change of intracellular potassium concentration per unit of protein.

The raised morning plasma renin activity and aldosterone secretion rate $(202 \mu \mathrm{g} . / 24$ hours $)$ after 11 days on the lowsodium diet are expected findings compatible with current concepts of the regulation of body sodium by the reninaldosterone system. After 15 days of carbenoxolone the early morning plasma renin was unchanged, but aldosterone secretion had decreased by two-thirds to a subnormal rate of $74 \mu \mathrm{g}$./ 24 hours. 
If liquorice or its derivatives stimulated the adrenal to produce aldosterone, or inhibited aldosterone metabolism, a rise in aldosterone excretion would be expected. If liquorice or derivatives have aldosterone-like action aldosterone excretion will be suppressed. The published results in man for liquorice and glycyrrhizinic acid are consistent; there is normal or reduced aldosterone excretion (Mollaret, Goulon, and Tournilhac, 1960 ; Drosdowski, Robel, and Sebaoun, 1961 ; Garcin, Goulon, Tournilhac, and Amor, 1961 ; Jenny, Muller, Fabre, and Mach, 1961 ; Salassa, Mattox, and Rosevear, 1962 ; Minivielle, Cristol, and Badach, 1963 ; Conn, Rovner, and Cohen, 1968) and secretion (Jenny et al., 1961 ; Conn et al., 1968). Plasma renin activity is also suppressed (Conn et al., 1968). These changes are reversible on stopping the liquorice preparations and can be produced again by restarting them.

The results reported here with carbenoxolone, a glycyrrhetinic acid salt, as well as the reports with glycyrrhizinic acid or liquorice, are consistent only with the hypothesis that the mireralocorticoid effect of carbenoxolone is due to its possessing intrinsic aldosterone-like properties. The unchanged morning plasma renin activity after carbenoxolone would suggest that the suppression of aldosterone secretion by carbenoxolone is not renin-mediated. It is most unlikely that a change in A.C.T.H. secretion was responsible for this fall in aldosterone secretion, since liquorice and its derivatives have little or no glucocorticoid activity (Baron and Nabarro, 1968, p. 150). We therefore suggest that this fall in aldosterone secretion is related to the fall in plasma potassium concentration (Laragh and Stoerk, 1957). Since we did not observe any change in external potassium balance our results suggest that aldosterone secietion is related to potassium concentration outside cells rather than inside cells.

The side-effects of carbenoxolone can be related to its mineralocorticoid effect and can be prevented by simultaneous administration of spironolactone, though at the cost of loss of therapeutic effect of ulcer-healing (Doll, Langman, and Shawdon, 1968). The side-effects could also be lessened by the diuretic hydrochlorothiazide without loss of ulcer-healing effect but at the expense of potassium depletion (Doll et al., 1968), and it is likely that a restricted sodium intake would prevent side-effects of carbenoxolone without loss of healing powers and without potassium depletion.

We are indebted to the patient for permitting us to make these studies. We wish to thank Miss McLaughlin, chief dietitian, Middlesex Hospital, for the balance diet; Sister Barnard for care of the patient; Mrs. M. Payne and Miss P. Batters for their assistance; and Dr. Miller, of the Courtauld Institute of Biochemistry, for the routine blood tests. The support by the Wellcome Trust of J.H.B. and J.D.H.S. is gratefully acknowledged.

\section{REFERENCES}

Baron, J. H., and Nabarro, J. D. N. (1968). In Symposium on Carbenoxolone Sodium, edited by J. M. Robson and F. M. Sullivan, p. 127. London, Butterworths.

Conn, J. W., Rovner, D. R., and Cohen, E. L. (1968). Fournal of the American Medical Association, 205, 492. Doll, R., Langman, M. J. S., and Shawdon, H. H. (1968). Gut, 9, 42.
Drosdowski, M., Robel, P., and Sebaoun, J. (1961). Presse Médicale, 69,

Garcin, R., Goulon, M., Tournilhac, M., and Amor, B. (1961). Revue Neurologique, 104, 461.

Jenny, M., Muller, A. F., Fabre, J., and Mach, R. S. (1961). Schweizerische medizinische Wochenschrift, 91, 869 .

Laragh, J. H., and Stoerk, H. C. (1957). fournal of Clinical Investigation, 36, 383 .

Minivielle, J., Cristol, P., and Badach, L. (1963). Presse Médicale, 71, 2021 .

Mollaret, P., Goulon, M., and Tournilhac, M. (1960). Bulletins et Mémoirs de la Société Médicale des Hôpitaux de Paris, 76, 491.

Salassa, R. M., Mattox, V. R., and Rosevear, J. W. (1962). Fournal of Clinical Endocrinology and Metabolism, 22, 1156.

Slater, J. D. H., et al. (1969). Clinical Science. In press.

Tuffley, R. E., and Slater, J. D. H. (1969). In preparation.

\title{
Blood Platelet Behaviour During and After Open-heart Surgery
}

\author{
F. N. MCKENZIE,* M.B.; \\ D. P. DHALL, $\dagger$ M.B., PH.D., F.R.C.S.ED.; K.-E. ARFORS, $\ddagger$ PH.D. \\ S. NORDLUND, $\S$ M.D. ; N. A. MATHESON,\| CH.M., F.R.C.S., F.R.C.S.ED.
}

British Medical fournal, 1969, 2, 795-798

\begin{abstract}
Summary : In view of the high incidence of thromboembolic complications after the insertion of cardiac vaive prostheses, platelet adhesiveness and aggregation was measured in whole blood before, during, and for several days after this operation in 10 patients. Cardiopulmonary bypass resulted in a profound decrease in the platelet count, in the number of adhesive platelets, and in platelet aggregation. These changes returned to near preoperative levels by the sixth postoperative day. Thereafter a consistent and sustained increase in platelet count, in the number of adhesive platelets, and in platelet aggregation was observed. The results suggest that the prevalence of thromboembolism after valve replacement may be due partly to changes in platelet behaviour.

* House Surgeon, Royal Infirmary, Aberdeen.

$\dagger$ Registrar, Royal Infirmary, Aberdeen. $\$$ Department of Clinical Physiology, Academic Hospital, Uppsala,

5 Department of Surgery, Norrkoping, Sweden.

II Consultant Surgeon, Royal Infirmary, Aberdeen.
\end{abstract}

The operative mortality of acquired cardiac valvular disease has fallen in recent years. Nevertheless, several detailed follow-up studies have shown an alarming incidence of both fatal and non-fatal postoperative arterial thromboembolic complications (Table I). From these studies it is clear that thromboembolic complications comprise the most important factor responsible for the delayed mortality and morbidity after heart valve replacement.

The role of platelets in thrombosis has been recognized for many years, and abnormalities in platelet behaviour have been shown to follow surgical operations (Wright, 1942 ; Emmons and Mitchell, 1965 ; Hampton and Mitchell, 1966; Bennett, 1967). Bygdeman et al. (1966) suggested that there is a correlation between the degree of increase in platelet adhesiveness and the subsequent development of venous thrombosis in surgical patients. Since patients undergoing open-heart surgery are exposed to a high risk of thromboembolic complications it appeared to be of value to examine their platelet response. 